\title{
Exploring the Impact of Transformational Leadership on Process Innovation and Product Innovation: A Case of Iraqi Public Universities
}

\author{
Hussain K. Hussain ${ }^{1}$, Noraini Abu Talib ${ }^{1} \&$ Ishak Mad Shah ${ }^{1}$ \\ ${ }^{1}$ Faculty of Management, Universiti Teknologi Malaysia, Johor Bahru, Malaysia \\ Correspondence: Hussain K. Hussain, Faculty of Management, Universiti Teknologi Malaysia, Johor Bahru, \\ Malaysia. E-mail: hussaink763@yahoo.com
}

Received: August 19, 2014 Accepted: September 9, 2014 Online Published: October 30, 2014

doi:10.5539/ass.v10n21p168

URL: http://dx.doi.org/10.5539/ass.v10n21p168

\begin{abstract}
Leadership plays an important role in stimulation of creativity among employees and establishment of innovative environment in organizations. Higher education sector of any country acts as a backbone for that country as it provides skilled human resource. The higher education in Iraq face many challenges, such as brain drain, employee morale and satisfaction that leads to lower innovation. In academic context, the leadership has a critical role in achieving success. The academic leadership of a higher education institution, more specifically transformational leadership, is responsible for process and product innovation by adopting policies and culture that would lead to employee's creativity and institution's more innovation. Therefore, the main purpose of the study is to examine the influence of transformational leadership on process and product innovation in higher education in Iraq. The quantitative data was collected through survey instrument. The sample for this study is teaching staff in 10 public universities distributed throughout Iraq. The sample consists of 280 academic staff members selected through random sampling technique. SPSS was used to analyze the data. The results found that there are significant strong relationships between the transformational leadership and the Process innovation. And significant strong relationships between the transformational leadership and the product innovation More importantly, there is significant impact of transformational leadership on both process and product innovation. In addition, transformational leadership plays an important role in determining innovation.
\end{abstract}

Keywords: transformational Leadership, process innovation, product innovation, higher education, Iraq

\section{Introduction}

In today's world the role of leadership in controlling the organizational factors varies. This is mainly because the humans possess abilities that differ across humans. These abilities are either acquired through experience or through intellectual training. These abilities help some individuals to influence others. Similarly, leaders have the abilities based on experience, traits and characteristics to influence other people within an organization. Organizations of all sizes need leadership that could provide direction as well as create an environment where organizational and cultural factors are at congruence with each other, thus helping the organization to succeed in its strategic environment (Birasnav et al., 2013; Chen et al., 2006; Garrison \& Vaughan, 2013; Sotirofski, 2011) are of the opinion that transformational leadership understands, organizations can only be transformed into innovative organizations, when human capital is created within the organizations. To develop human capital, transformational leaders exercise empowerment among employees so that employees can make quicker decisions regarding innovations. Thomson (2007) has highlighted that the success of an organization depends on a number of factors like human capital, availability of technological and financial resources etc. All these elements are interrelated and are integrated to achieve organizational objectives. For achievement of objectives and integration of resources, organizations are always on the lookout for a suitable person, who could help the organization in its achievement of objectives. Iraqi higher education system suffered brain drain phenomenon as well and many of the intellectuals and scientists left the country. With lack of contact from the outside world Iraqi HEIs suffered in terms of research and development (Al-Janabi and Urban, 2011). Another important issue is the lack of security in Iraq, which has forced hundreds of scientific and intellectuals from various specializations to leave their universities. Iraq has been facing significant deterioration in HEIs because of weak international contact (Al-Janabi \& Urban, 2011; Almayali et al., 2012). "When mobility is limited or difficult, it 
becomes all the more important to enhance professional growth within the institution" (Johnsrud et al., 2000). Not surprisingly, then, staff members are "interested in improving their ability to do the job they have as well as gaining the skills and experience necessary to take on new and more challenging positions" (Rosser et al., 2000). Unfortunately, in Iraq due to lack of financial help to the universities, training and development of the employees is nearly lacking, which is also one of the cause of brain drain (Mahmud, 2013). The above highlighted are few of the issues that are faced by the Iraqi HEIs. These issues are challenges for the leadership of HEIs to overcome and make their institutions more competitive and bring about organizational innovation so much needed to redevelop the destroyed Iraqi higher education system. AL-Hakim and Hassan (2012a,b). From 1950 till 1990 Iraq had one of the most advanced higher educational systems in the Arab world (Janabi \& Urban, 2011). In 1991, economic sanctions were imposed by the United Nations Security Council on Iraq after its occupation and subsequent release of Kuwait. These sanctions lasted from 1991 till middle of 2003. These decade long economic sanctions had hurt the Iraqi higher education sector badly leading to destruction of infrastructure, information technology and reduced support for the higher education academic community. Among other things many of the universities such as University of Basra and Al-Mustansiriya were plundered by the people These sanctions and the three decades of wars separated Iraq from global developments especially in science and technology and hampered the overall innovation capability of the Iraqi HEIs (Asif et al., 2013). Furthermore, it has been highlighted that the leadership of Iraqi universities needs to expend effort and design strategies on promoting activities among the academic staff that could promote innovativeness (Al-Husseini \& Elbeltagi, 2014).

\subsection{Relationship between Transformational Leadership and Innovation}

Transformational leadership focus on developing human capital that helps in transformation of organization into innovative organization (Birasnav et al., 2013). For development of human capital in organizations, it is necessary that they should be empowered so they could take decisions on their own affecting innovation and creativity. To achieve organizational objectives and for organizational success, factors like human capital, technology, financial resource etc are needed; but to integrate all the factors is a responsibility of a leader (Thomson, 2007). Thus, leaders are expected to have certain characteristics that would distinguish them from other employees. Researchers have highlighted that leadership behavior like participative and considerate would increase creativity of subordinates (Hage \& Dewar, 1973). Similarly, researchers are of the opinion that leaders, who help in the development of cognitive skills of their subordinates, give them empowerment and provide conducive and supportive environment would help raise the creativity levels of their subordinates (Oldham \& Cummings, 1996; Redmond et al., 1993; Scott \& Bruce, 1994; Tierney et al., 1999).Literature is replete with studies that confirm transformational leaders' role in enhancing employees' creativity and innovation. The research highlights that leaders who follow transformational style help raise the employees' engagement levels within an organization (Bass, 1985; Gardner et al., 1998; Shamir et al., 1993), by providing motivation through articulating a vision that links organizational and employees' interests together and thus, in the process not only help employees' to achieve organizational objectives but also their own personal objectives (Bennis \& Nanus, 1985; Conger \& Kanungo, 1998; House et al., 1991). There are several studies that have observed a positive and significant relationship between transformational leadership and innovation (Keller, 1992; Sosik et al., 1998), transformational leadership, intellectual stimulation and supportive environment (Howell \& Avolio, 1993). Innovation in organizations is more than creativity or invention (Van de Ven, 1986). However, vision is a significant building block for innovation (Amabile \& Gryskiewicz, 1989). An invention or creative idea does not become an innovation until it is accepted organization wide (Van de Ven, 1986). Fuglsang (2010) measured the term "innovation" to be comprehensive of actions such as implementation, diffusion, replication, and gaining wider positive advantage from the invention. The innovation process is often contentious, competes with other courses of achievement, and poses a threat to vested welfares (Kanter, 1988). An organization's skill to innovate and harness creativity is critical for its survival in a rapidly changing environment especially for the public sector. The current shrinking budget environment have generated a loss of long-term predictability for the existence of many organizations within the public sector Therefore, public organizations must improve their chances for survival and longevity by increasing "variations" via innovation (Linden, 1990). Public sector organizations are burdened by an additional dimension of limitations and restrictions compared to sector entities. However, Metcalfe (1993) points that government organizations work in an interdependent network and are unlike their independent counterparts in private sector. The stringent central agency restraints to minimize corruption and transparency can make barriers to innovation (Borins, 2001). Innovative actions create alteration, increased risk, uncertainty, and imprecision (Kirton, 1976). As such, most innovations in organizations inexorably experience confrontation and often become a subject of debate within an organization (Borins, 2002). 
It has been suggested that high commitment work place practices can be used to align organizational and employees' objectives (Metcalfe, 1993), to achieve organizational change outcomes (Antonioli \& Mazzanti, 2011), which are characterized by higher productivity for the organization and higher job satisfaction for the employees (Askenazy, Handel \& Levine, 2004). However, when support for innovation was absent, the positive relationship became insignificant. This pair of findings provides indirect support for the leader's role in inducing creativity. Keller (2006) also found that transformational leadership positively influenced performance of research and development $(R \& D)$ project teams in a large $R \& D$ organization. Performance was measured based on superiors' ratings of subordinate innovativeness and the extent to which their innovative orientation added unique value to the projects that they finished. Thus, the above arguments lead to the following hypothesis:

H1: There is significant relationship between transformational leadership and process innovation.

$\mathrm{H} 2$ : There is significant relationship between transformational leadership and product innovation

H3: There is significant impact of transformational leadership on process innovation.

H4: There is significant impact of transformational leadership on product innovation.

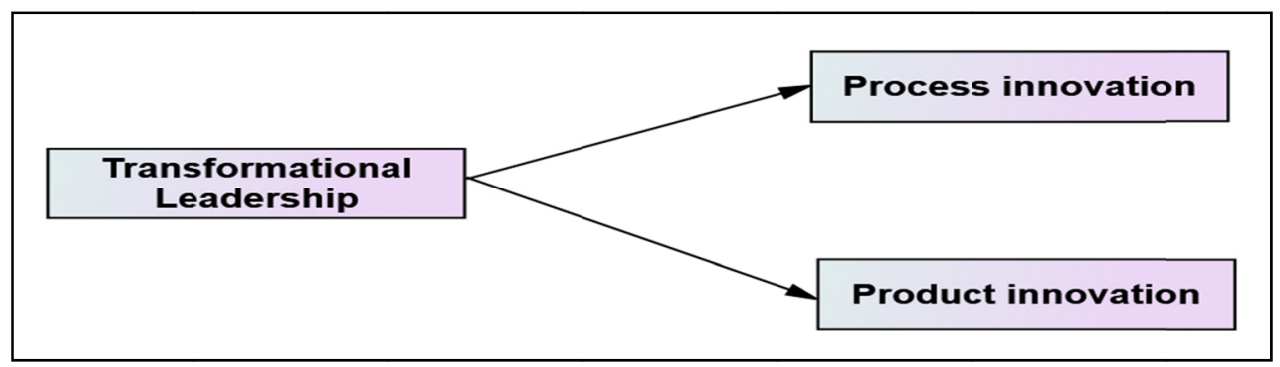

Figure 1. Model of the study

\section{Method}

This correlation and causal research attempted to describe the relationship among the variables and the influence of independent variable on dependent variable. Pearson correlation was used to ascertain the relationship between the variables of the study and regression attempted to describe the influence among the variables. The quantitative data was collected through survey instrument using five point likert scale. The population for this study consisted of academic staff in 10 public universities distributed throughout Iraq. The sample consisted of 280 academic staff members selected through random sampling technique.

\subsection{Instruments Measurement}

Multifactor Leadership Questionnaire (MLQ short Form 5X) was used to measure transformational leadership (Bass, 1997; Avolio \& Bass, 1995). The MLQ is one of the most widely used instruments to measure transformational and transactional leader behaviors in the organizational sciences (Tejeda et al., 2001). This instrument is widely used to measure transformational leadership in different countries in the world and the validity and reliability of this scale have been established through previous research (Hartog et al., 1997). Participants were asked to describe their supervisor's leadership behavior on 20 items based on transformational leadership. A five-point Likert scale was used with the responses ranging from ( $1=$ not at all; to $5=$ frequently, if not always). In the MLQ (Form5X), transformational leadership is measured via the use of the five dimensions of transformational leadership. The dimensions were measured by the four items for each, such as Inspirational Motivation IM, Intellectual Stimulation IS, Idealized Influence (behavior) IIB, Idealized Influence (attributed) IIA and Individualized Consideration IC.

Process Innovation Questionnaire has been measured using 3 items adapted from Tsai et al. (2008), 4 items measured product innovation. Using a 5-point likert scale, respondents are asked to indicate the extent of their agreement with each item ranging from 1 (strongly disagree) to 5 (strongly agree). The reported Cronbach's alpha reliability for the scale is 0.93 (Easa, 2012).

\section{Results}

\subsection{Reliability}

Reliability was tested for each variable of transformational leadership, Process innovation and Product innovation. To measure the consistency of the scale, Cronbach alpha was used as a measure of reliability. 
Reliability coefficients of 0.7 or more are considered adequate for social studies. Table 1 shows an acceptable range of reliability for the variables of the study.

Table 1 . The reliability result for transformational leadership, process innovation and product innovation

\begin{tabular}{llcc}
\hline No. & variable & Number of items & Cranach's Alpha \\
\hline 1 & Transformational Leadership & 20 & 0.92 \\
2 & Process Innovation & 3 & 0.80 \\
3 & Product Innovation & 4 & 0.85 \\
\hline
\end{tabular}

\subsection{Correlation Analysis}

Pearson correlation was used to determine the relationship between transformational leadership, process innovation and product innovation.

Table 2. The correlation result

\begin{tabular}{llllll}
\hline Variable & 1 & 2 & 3 & Mean & $S D$ \\
\hline Transformational Leadership & $\mathbf{( 0 . 9 2 )}$ & & & 3.44 & 0.61 \\
Process Innovation & $0.606^{* *}$ & $\mathbf{( 0 . 8 0 )}$ & & 3.36 & 0.86 \\
Product Innovation & $0.474^{* *}$ & $0.541^{* *}$ & $\mathbf{( 0 . 8 5 )}$ & 3.26 & 0.88 \\
Number of items & 20 & 3 & 4 & & \\
\hline
\end{tabular}

Correlation is significant at the level (2-tailed)

(SD Standard Deviation)

Table 2 shows Pearson Correlation Coefficient values for the variables. The relationship between transformational leadership and process innovation is $\left(0.606^{* *}\right)$ and for transformational leadership and product innovation is $\left(0.474^{* *}\right)$, which are significant at 0.01 . This means transformational leadership has strong and significant relationship with both process and product innovations. Thus, the correlation results support the first and second hypotheses of the study as mentioned below.

\subsection{Regression Analysis}

To measure the impact of transformational leadership on product innovation and process innovation, linear regression analysis was used. The regression analysis measures the impact of independent variables on the dependent variable.

Table 3. Regression analysis results

\begin{tabular}{cccccccc}
\hline Variable & $\begin{array}{c}\text { Standard } \\
\text { Beta }\end{array}$ & Sig. & $R^{2}$ & $\begin{array}{c}\text { Adjusted } \\
R^{2}\end{array}$ & $\begin{array}{c}\text { Standard } \\
\text { Error }\end{array}$ & $\begin{array}{c}F \\
\text { statistics }\end{array}$ & $p$-value \\
\hline Process Innovation & 0.61 & 0.000 & 0.37 & 0.37 & 0.69 & 161.09 & 0.000 \\
Product Innovation & 0.47 & 0.000 & 0.23 & 0.22 & 0.78 & 80.63 & 0.000 \\
\hline
\end{tabular}

To test the hypotheses H3 and H4 as indicated below, regression analysis using simple linear regression technique was used.

H3: There is significant impact of transformational leadership on process innovation.

H4: There is significant impact of transformational leadership on product innovation

Statistical results for regression analysis are shown in Table 3. The results illustrate the model fitness indicated by the $F$-statistics for both process innovation $(F 161.09, \mathrm{p}<0.01)$ and product innovation $(F 80.63, \mathrm{p}<0.01)$. The $R^{2}$ value indicates the strength of the relationship, which is for process innovation $\left(R^{2}=0.37\right)$ and for product innovation is $\left(R^{2}=0.23\right)$. The beta coefficient indicates the influence of independent variable on the dependent variable. The beta coefficient results for process innovation $(\beta=0.61, \mathrm{p}<0.01)$ and product innovation $(\beta=0.47, p<0.01)$ indicate that transformational leadership is having an influence of 61 percent on the process innovation and 47 percent influence on product innovation. Both the influences are significant as the significance value is $p<0.01$. Thus, the regression results support our H3 and H4 hypotheses as indicated above.

\section{Conclusion}

The above statistical results prove that there are significant strong relationship between the transformational leadership and process innovation and significant strong relationship between the transformational leadership 
and product innovation. More importantly, there are significant impacts of the transformational leadership on both process and product innovation. In others words, it indicates that all of the transformational leadership are contributing significantly to innovation. Leaders are the key personnel within organizations giving directions and guiding employees to be more creative in their approaches. They are the ones who are responsible for ensuring a suitable environment that could lead to innovation.

\section{References}

AL-Hakim, L. A. Y., \& Hassan, S. (n. d.). The Relationships among Knowledge Management Processes, Innovation, and Organisational Performance in the Iraqi MTS.

Al-Husseini, S., \& Elbeltagi, I. (n. d.). Knowledge Sharing Practices as a Basis of Product Innovation: A Case of Higher Education in Iraq.

Al-Husseini, S., \&Elbeltagi, I. (2014). Transformational leadership and innovation: A comparison study between Iraq's public and private higher education. Studies in Higher Education (ahead-of-print), 1-23. http://dx.doi.org/10.1080/03075079.2014.927848

Al-Janabi, S., \& Urban, J. E. (2011). Strategic plan for enhancing higher education computing degree programs in Iraq. Paper presented at the Global Engineering Education Conference (EDUCON), 2011 IEEE. http://dx.doi.org/10.1109/EDUCON.2011.5773120

Almayali, H. H., Ahmad, B., \& Ariffin, Z. (2012). Leadership Behaviours and Academic Performance in Iraqi Public Universities: A Review. Information Management \& Business Review, 4(12).

Amabile, T. M., \& Gryskiewicz, Nur D. (1989). The creative environment scales: Work environment inventory. Creativity Research Journal, 2(4), 231-253. http://dx.doi.org/10.1080/10400418909534321

Antonioli, B., \& Mazzanti, M. (2011). Strategie di innovazione e risultati economici. Un'indagine sulle imprese manifatturiere dell'Emilia Romagna. FrancoAngeli.

Asif, M., Raouf, A., \& Searcy, C. (2013). Developing measures for performance excellence: is the Baldrige criteria sufficient for performance excellence in higher education? Quality \& Quantity, 47(6), 3095-3111. http://dx.doi.org/10.1007/s11135-012-9706-3

Askenazy, P. C. (2006). Innovative Work Practices, Information Technologies and Working Conditions: Evidence for France. IZA Discussion Paper.

Avolio, B. J., \& Bass, B. M. (1995). Individual consideration viewed at multiple levels of analysis: A multi-level framework for examining the diffusion of transformational leadership. The Leadership Quarterly, 6(2), 199-218. http://dx.doi.org/10.1016/1048-9843(95)90035-7

Bass, B. M. (1985). Leadership and performance beyond expectations. Collier Macmillan.

Bass, B. M. (1997). Does the transactional-transformational leadership paradigm transcend organizational and national boundaries? American psychologist, 52(2), 130. http://dx.doi.org/10.1037/0003-066X.52.2.130

Bennis, W. G., \& Nanus, B. (1985). Leaders. Harper \& Row New York.

Birasnav, M., Albufalasa, M., \& Bader, Y. (2013). The role of transformational leadership and knowledge management processes on predicting product and process innovation: An empirical study developed in Kingdom of Bahrain. Tékhne, 11(2), 64-75. http://dx.doi.org/10.1016/j.tekhne.2013.08.001

Borins, S. (2001). Encouraging innovation in the public sector. Journal of intellectual capital, 2(3), 310-319. http://dx.doi.org/10.1108/14691930110400128

Borins, S. (2002). Leadership and innovation in the public sector. Leadership \& Organization Development Journal, 23(8), 467-476. http://dx.doi.org/10.1108/01437730210449357

Chen, S.-H., Yang, C.-C., Shiau, J.-Y., \& Wang, H.-H. (2006). The development of an employee satisfaction model for higher education. The TQM Magazine, 18(5), 484-500. http://dx.doi.org/10.1108/ 09544780610685467

Conger, J. A., \& Kanungo, R. N. (1998). Charismatic leadership in organizations. Sage.

Easa, N. F. (2012). Knowledge Creation Process and Innovation in the Egyptian banking sector: Methodological Aspects. Proceedings of the 20th EDAMBA Summer Academy, Soreza, France.

Fuglsang, L. (2010). Bricolage and invisible innovation in public service innovation. Journal of Innovation Economics, (1), 67-87. http://dx.doi.org/10.3917/jie.005.0067 
Gardner, D. G., Cummings, L. L., Dunham, R. B., \& Pierce, J. L. (1998). Single-item versus multiple-item measurement scales: An empirical comparison. Educational and Psychological Measurement, 58(6), 898-915. http://dx.doi.org/10.1177/0013164498058006003

Garrison, D. R., \& Vaughan, N. D. (2013). Institutional change and leadership associated with blended learning innovation: Two case studies. The Internet and Higher Education, 18, 24-28. http://dx.doi.org/ 10.1016/j.iheduc.2012.09.001

Hage, J., \& Dewar, R. (1973). Elite values versus organizational structure in predicting innovation. Administrative science quarterly, 18(3). http://dx.doi.org/10.2307/2391664

Handel, M. J., \& Levine, D. I. (2004). Editors' introduction: The effects of new work practices on workers. Industrial Relations: A Journal of Economy and Society, 43(1), 1-43.

Hartog, D. N., Muijen, J. J., \& Koopman, P. L. (1997). Transactional versus transformational leadership: An analysis of the MLQ. Journal of occupational and organizational psychology, 70(1), 19-34. http://dx.doi.org/10.1111/j.2044-8325.1997.tb00628.x

House, R. J., Spangler, W. D., \& Woycke, J. (1991). Personality and charisma in the US presidency: A psychological theory of leader effectiveness. Administrative science quarterly, 36(3). http://dx.doi.org/ $10.2307 / 2393201$

Howell, J. M., \& Avolio, B. J. (1993). Transformational leadership, transactional leadership, locus of control, and support for innovation: Key predictors of consolidated-business-unit performance. Journal of applied psychology, 78(6), 891. http://dx.doi.org/10.1037/0021-9010.78.6.891

Johnsrud, L. K., Heck, R. H., \& Rosser, V. J. (2000). Morale matters: Midlevel administrators and their intent to leave. Journal of Higher Education, 34-59. http://dx.doi.org/10.2307/2649281

Kanter, R. M. (1988). Three tiers for innovation research. Communication Research, 15(5), 509-523.

Keller, R. T. (1992). Transformational leadership and the performance of research and development project groups. Journal of management, 18(3), 489-501. http://dx.doi.org/10.1177/014920639201800304

Keller, R. T. (2006). Transformational leadership, initiating structure, and substitutes for leadership: A longitudinal study of research and development project team performance. Journal of applied psychology, 91(1), 202. http://dx.doi.org/10.1037/0021-9010.91.1.202

Kirton, M. (1976). Adaptors and innovators: A description and measure. Journal of applied psychology, 61(5), 622. http://dx.doi.org/10.1037/0021-9010.61.5.622

Linden, R. M. (1990). From vision to reality: Strategies of successful innovators in government: Lel Enterprises Charlottesville, Virginia.

Mahmud, S. F. (2013). The Higher Education In Iraq Challenges And Recommendations. Journal of Advanced Social Research Vol, 3(9), 255-264.

Metcalfe, L. (1993). Public management: from imitation to innovation. Australian Journal of Public Administration, 52(3), 292-304. http://dx.doi.org/10.1111/j.1467-8500.1993.tb00281.x

Oldham, G. R., \& Cummings, A. (1996). Employee creativity: Personal and contextual factors at work. Academy of management journal, 39(3), 607-634. http://dx.doi.org/10.2307/256657

Redmond, M. R., Mumford, M. D., \& Teach, R. (1993). Putting creativity to work: Effects of leader behavior on subordinate creativity. Organizational behavior and human decision processes, 55(1), 120-151.

Rosser, J. C., Herman, B., Risucci, D. A., Murayama, M., Rosser, L. E., \& Merrell, R. C. (2000). Effectiveness of a CD-ROM multimedia tutorial in transferring cognitive knowledge essential for laparoscopic skill training. The American journal of surgery, 179(4), 320-324. http://dx.doi.org/10.1016/S0002-9610 (00)00342-1

Scott, S. G., \& Bruce, R. A. (1994). Determinants of innovative behavior: A path model of individual innovation in the workplace. Academy of management journal, 37(3), 580-607. http://dx.doi.org/10.2307/256701

Shamir, B., House, R. J., \& Arthur, M. B. (1993). The motivational effects of charismatic leadership: A self-concept based theory. Organization science, 4(4), 577-594. http://dx.doi.org/10.1287/orsc.4.4.577

Sosik, J. J., Kahai, S. S., \& Avolio, B. J. (1998). Transformational leadership and dimensions of creativity: Motivating idea generation in computer-mediated groups. Creativity Research Journal, 11(2), 111-121. 
Sotirofski, K. (2011). Comparing the educational leadership roles of Albanian and Turkish higher education institutions administrators. Procedia-Social and Behavioral Sciences, 15, 3560-3565.

Tejeda, M. J., Scandura, T. A., \& Pillai, R. (2001). The MLQ revisited: Psychometric properties and recommendations. The Leadership Quarterly, 12(1), 31-52. http://dx.doi.org/10.1016/S1048-9843(01) 00063-7

Thomson, G. S. (2007). A review of transformational leadership models and its linkage to the scholarship/practice/leadership model.

Tierney, P., Farmer, S. M., \& Graen, G. B. (1999). An examination of leadership and employee creativity: The relevance of traits and relationships. Personnel Psychology, 52(3), 591-620.

Tsai, W. - F., Huang, W., Lin, F. - P., Hung, B., Wang, Y. - T., Shiau, S., ... Pan, Y. - L. (2008). The human centered cyberinfrastructure for scientific and engineering grid applications. Journal of the Chinese institute of engineers, 31(7), 1127-1139. http://dx.doi.org/10.1080/02533839.2008.9671468

Van de Ven, A. H. (1986). Central problems in the management of innovation. Management science, 32(5), 590-607. http://dx.doi.org/10.1287/mnsc.32.5.590

\section{Copyrights}

Copyright for this article is retained by the author(s), with first publication rights granted to the journal.

This is an open-access article distributed under the terms and conditions of the Creative Commons Attribution license (http://creativecommons.org/licenses/by/3.0/). 